The PAKISTAN

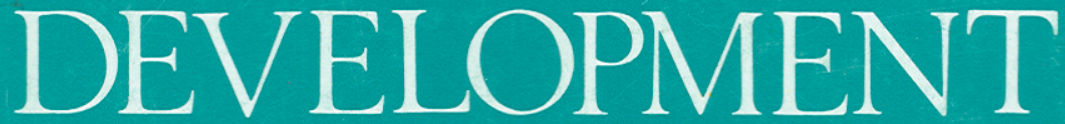

REVIEW

An International Journal of Development Economics

\section{Editor}

SYED NAWAB HAIDER NAQVI

Co-editor

SHAMIM A. SAHIBZADA

Associate Literary Editor

MIR ANNICE MAHMOOD

\section{Papers and Proceedings}

\section{PART II}

Tenth Annual General Meeting

of the

Pakistan Society of Development Economists

Islamabad, April 2-5, 1994 


\section{PAKISTAN SOCIETY OF DEVELOPMENT ECONOMISTS \\ Pakistan Institute of Development Economics \\ Quaid-i-Azam University Campus \\ Post Box 1091, ISLAMABAD \\ (Pakistan)}

The Pakistan Society of Development Economists (PSDE) is an autonomous, non-profit professional body. based in Pakistan Institute of Development Economics (PIDE). The Society provides a forum and platform to the academics and policy-makers for exchanging ideas on the pressing economic and social problems facing Pakistan. The Society organises conferences and seminars on topical themes in development economics to promote a better understanding of the mystique of economic development, and arranges lectures on Development Economics by economists and demographers of international repute. The Society confers awards on scholars who make seminal contributions. The membership of the Society is restricted to those working in the general area of Development Economics and related disciplines. The Society is registered under the Societies Registration Act, 1860.

\section{GOVERNING COUNCIL}

Syed Nawab Haider Naqvi, President, PSDE

\section{Muhammad Afzal \\ Rafiq Ahmed \\ H. U. Beg \\ M. Fazil Janjua}

\author{
Aftab Ahmad Khan \\ Akhtar Hasan Khan \\ Ashfaq Mahmood
}

Shamim A. Sahibzada, Secretary

EXECUTIVE COUNCIL

Syed Nawab Haider Naqvi, Chairman
Shoaib Sultan Khan

Ghulam Hussain Khaskhelly

M. M. Malik

Mian M. Nazeer

M. Fazil Janjua

\section{Rafiq Ahmed}

Mahfooz Ali

H. U. Beg
Mian M. Nazeer

Naseer A. Shaikh

Javed Talat

Muhammad Yaqub

\author{
Asghar Qadir \\ Ghulam Rasul \\ M. Nazir Romani \\ Agha Shahi
}

Shukurullah

Shamim A. Sahibzada, Secretary

Abdul Hameed, Treasurer

Published by the Pakistan Institute of Development Economics, Islamabad and printed at Crystal Printer, Islamabad, with partial financial assistance by Friedrich Ebert Stiftung, Islamabad. 


\section{CONTENTS}

PRIVATISATION AND PUBLIC SECTOR ISSUES

A. F. Aisha Ghaus and Hafiz A. Pasha. Dynamic Budgetary Consequences of the 1991 NFC Award

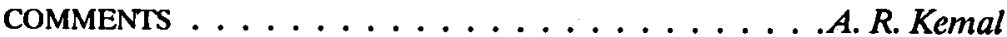

Jomo K. S. Privatisation and Public Sector Reform: The Political Economy of State Intervention

COMMENTS . . . . . . . . . . . . . Mir Annice Mahmood

\section{DEMOGRAPHIC ANALYSIS}

Mohammad Afzal, S. Mubashir Ali and H. B. Siyal. Consanguineous Marriages in Pakistan

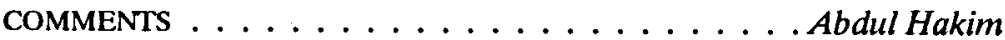

M. Naseem Iqbal Farooqui. Interpersonal Communication in Family Planning in Pakistan

Abdul Hakim. Factors Affecting Fertility in Pakistan

685

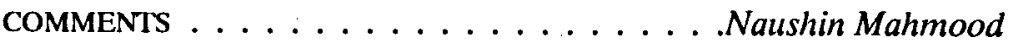

Khaleda Manzoor. Costeffectiveness of the Family Planning Programme in Pakistan

Azra Aziz. Proximate Determinants of Fertility in Pakistan

COMMENTS . . . . . . . . . . . . . Syed Mubashir Ali

\section{ISSUES IN HEALTH SECTOR}

Rehana Siddiqui and Mir Annice Mahmood. The Determinants of Health Status: A Cross-Country Analysis

Naushin Mahmood and M. Framurz K. Kiani. Health Care Determinants of Child Survival in Pakistan 
Tauseef Ahmed. Contraceptive Methods Choice in Pakistan: Determined or Predetermined

COMMENTS . . . . . . . . . . . Ghulam Yasin Soomro

\section{AGRICULTURAL DEVELOPMENT}

M. Ghaffar Chaudhry and Shamim A. Sahibzada. Comparative Advantage in Pakistan's Agriculture: The Concept and the Policies

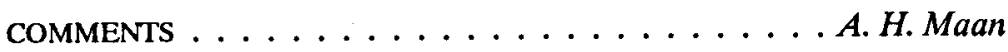

Amir Mahmood and M. Ghaffar Chaudhry. Self-reliance Policy in Edible Oil and the Social Profitability of Pakistan's Oilseed Crops

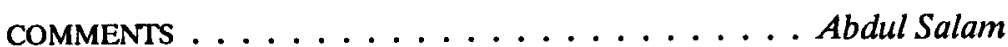

Rao Abdul Rauf Khan. Farm Loans Recovery Problem in Pakistan: Its Possible Solution

Sarfraz Khan Qureshi, Zakir Hussain and Zeb-un-Nisa. An Assessment of Warabandi (Irrigation Rotation) in Pakistan: A Preliminary Analysis

Ruth Meinzen-Dick. Private Tubewell Development and Groundwater Markets in Pakistan: A District-level Analysis

Ather Maqsood Ahmed and Rizwana Siddiqui. Supply Response in Pakistan with "Endogenous" Technology

COMMENTS . . . . . . . . . . . . Amir Mahmood

Mohammad Aslam Chaudhary. Regional Agricultural Underdevelopment in Pakistan

COMMENTS ................... Ghaffar Chaudhry

\section{INEQUALITY AND POVERTY}

A. R. Kemal. Structural Adjustment, Employment, Income Distribution and Poverty 
M. Asghar Zaidi and Klaas de Vos. Trend Analysis of Relative Poverty in Pakistan (1984-85 - 1987-88)

COMMENTS . . . . . . . . . . . . Rehana Siddiqui

Sohail J. Malik, Muhammad Hussain and Nasim S. Shirazi. Role of Infaq in Poverty Alleviation in Pakistan

COMMENTS . . . . . . . . . . . Shahrukh Rafi Khan

\section{FISCAL AND MONETARY ISSUES}

Tayyeb Shabbir and Ayaz Ahmed. Are Government Budget Deficits Inflationary? Evidence from Pakistan

COMMENTS . . . . . . . . . . M. Shaukat Ali

Akhtar Hossain. The Search for a Stable Money Demand Function for Pakistan: An Application of the Method of Cointegration

COMMENTS ................... Syed Sajid Ali

Faiz Bilquees and Shahnaz Rauf. Income Velocity and per Capita Income in Pakistan: 1974-75 to 1991-92

COMMENTS . . . . . . . . . . . . . Aliya H. Khan

Ashfaque H. Khan. Financial Liberalisation and the Demand for Money in Pakistan

COMMENTs .............................. Hossain

Zafar Iqbal. Macroeconomic Effects of Adjustment Lending in Pakistan

COMMENTS ........................ Bailquees

Syed Zahid Ali and W. M. Scarth. Can Devaluation Cause Perverse Effects if the Macroeconomy is Stable? 
Ahmed M. Khalid. Empirical Tests of the Rational ExpectationsPermanent Income Hypothesis: Evidence from Pakistan

Aqdas Ali Kazmi. Private Consumption, Government Spending, Debt Neutrality: Resolving Kormendi-Feldstein-Modigliani Controversy COMMENTS . . . . . . . . . . . . Ahmed M. Khalid

Rizwan Tahir. Estimating the Quantitative Importance of Various Sources of Macroeconomic Variability

Qazi Masood Ahmed. The Determinants of Tax Buoyancy: An Experience from the Developing Countries

Usman A. Afridi and Rehana Siddiqui. Framework for Deriving Real Exchange Rates

COMMENTS . . . . . . . . . . . . . Syed Zahid Ali

Kalbe Abbas and Tariq Mahmood. Fiscal Effects of Monetary Seigniorage: A Case Study of Pakistan

\section{WOMEN AND DEVELOPMENT}

Zeba A. Sathar and Bilquees Raza. Safe Motherhood in South Asia: Current Status and Strategies for Change

COMMENTS . . . . . . . . . . . . Sajida Samad

Nargis Sultana, Hina Nazli and Sohail J. Malik. Determinants of Female Time Allocation in Selected Districts of Rural Pakistan COMMENTS . . . . . . . . . . . . . Shahnaz Kazi

Zubeda Khan, Ghulam Y. Soomro and Samina Soomro. Mother's Education and Utilisation of Health Care Services in Pakistan 


\section{ISSUES IN DEVELOPMENT ECONOMICS}

Zafar H. Ismail, Hafiz A. Pasha and A. Rauf Khan. Cost Elfectiveness in Primary Education: A Study of Pakistan

COMMENTS ............... S. M. Younus Jafri

Soofia Mumtaz. The Rationale of Development Anthropology

\section{INTERNATIONAL ECONOMICS}

Akhtar Hasan Khan. The Impact of the Uruguay Round on World Economy

COMMENTS . . . . . . . . . . . . . Aqdas Ali Kazmi

M. Aynul Hasan and Ashfaque H. Khan. Impact of Devaluation on Pakistan's External Trade: An Econometric Approach

Sübidey Togan. Tariff Equilibrium with Customs Union

\section{HUMAN RESOURCE DEVELOPMENT}

Moazam Mahmood, Tariq Javaid and Ajmal Baig. Why Children do not Go to School in Pakistan-Some Estimates and a Theoretical Framework

COMMENTS ................. Shaheen Rafi Khan

Shahnaz Hamid. A Micro Analysis of Urban Child Labour: Some Determinants of Labour and its Conditions

COMMENTS ............................ . Ahmed

Durr-e-Nayab and Sabiha Ibrahim. The Appropriateness of a Community-based Programme: A Case-study of the AKRSP in Two Villages of Gilgit District 


\section{ISLAMIC ECONOMICS}

Muhammad Hussain. A Comprehensive Macroeconomic Income Determination Model for an Islamic Economy

Muhammad Anwar. Comparative Study of Insurance and Takafol (Islamic Insurance)

COMMENTS . . . . . . . . . . . Muhammad Hussain

\section{EMPLOYMENT ISSUES}

Shahnaz Kazi. Reabsorption of Returning Workers from the Gulf: The Asian Experience

Israrul Haque. The Significant Variables of Full Employment and their Explanatory Values

COMMENTS . . . . . . . . . . . . . A. Hussein Mullick

Sabur Ghayur. Developing Labour Market Information System for Informal Sector in Pakistan

COMMENTS . . . . . . . . . . . Israrul Haque

\section{ISSUES IN INDUSTRIAL SECTOR}

Shahnaz Rauf. Structure of Large-scale Manufacturing Industries of Pakistan (1950-1988)

Zafar Mahmood and Muhammad Ali Qasim. Wages versus Fringe Benefits in the Large-scale Manufacturing Sector of Pakistan

COMMENTS .............. Eshya Mujahid-Mukhtar

Zareen Fatima Naqvi. Distributional Impact of Public Enterprise Labour Policies in Pakistan

COMMENTS ................. Zafar Mahmood

\section{FINANCIAL MARKETS IN PAKISTAN}

Nasir M. Khilji. Nonlinear Dynamics and Chaos: Application to Financial Markets in Pakistan 
Khwaja Sarmad and Riaz Mahmood. Intersectoral Financial Transactions in Pakistan

Programme of the Tenth Annual General Meeting of the Pakistan Society of Development Economists 


\section{PRIVATISATION AND PUBLIC SECTOR ISSUES}




\title{
Dynamic Budgetary Consequences of the 1991 NFC Award
}

\author{
A. F. Aisha Ghaus and Hafiz A. Pasha
}

\section{INTRODUCTION}

The National Finance Commission (NFC) award of 1991 has been acclaimed to be a historic achievement of the previous elected government. It has come after a gap of many years (due since 1979) and some abortive attempts earlier. ${ }^{1}$ Meanwhile, the provinces had run into large, chronic deficits on the current account, indicating the growing inadequacy of divisible pool transfers as per the provisions of the 1974 award. Consequently, as an ad hoc provision, deficit grants and other subventions had been used increasingly to support the on-going operations of the provinces. At their peak in 1987-88, these grants were Rs 17 billion (see Table 1), equivalent to about 2 percent of the Gross Domestic Product (GDP) and financed over one-fourths of the provincial current expenditure. Also, the federal government took over the responsibility of provision of some provincial responsibilities as contained in the Concurrent List of the Constitution like SCARPS, flood control, fertiliser subsidy, universities, etc.

There had, however, been growing dissatisfaction with the existing pattern of inter-governmental fiscal relations in the country. On the one hand, the high and growing dependence on discretionary fiscal transfers had mitigated against financial autonomy and, on the other hand, the implied residual access to grants had left provinces with little incentive either to mobilise their own resources or to economise on their expenditure. Provincial own revenues grew only modestly, at about 11 percent, while provincial current expenditures increased at a rapid rate, approaching 18 percent. Contrary perhaps to expectations, rapid growth in federal

A. F. Aisha Ghaus and Hafiz A. Pasha are Research Economist and Director respectively at the Applied Economics Research Centre, University of Karachi, Karachi.

${ }^{1}$ According to Article 160 of the 1973 Constitution, the President of Pakistan is expected to constitute a NFC every five years to make recommendations on the distribution between the federation and provinces of the net proceeds of divisible pool taxes (as specified by the President), the making of grants-in-aid, and exercise of borrowing powers by the provinces. Two NFCs were constituted in 1979 and 1985 but no consensus could be reached among the provinces on the distribution formula. 


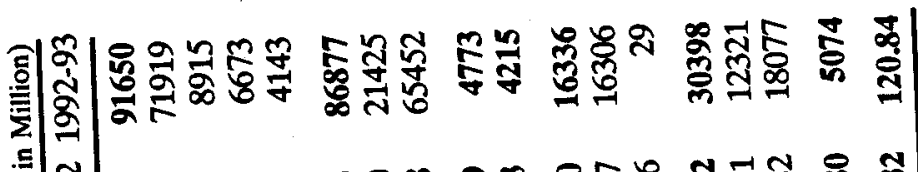

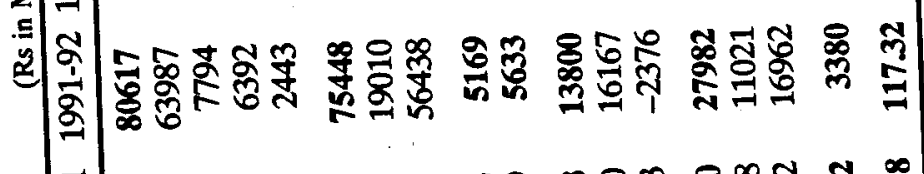

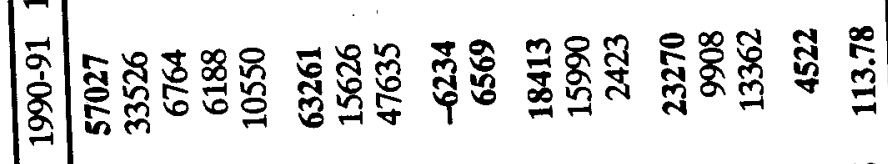

ठิ

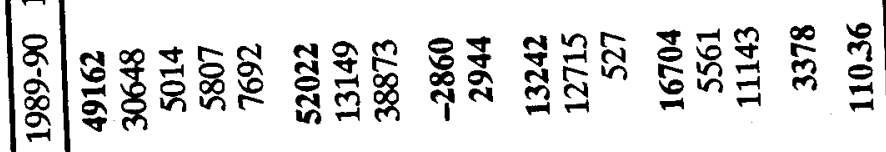

$\bar{\sigma} a$

ษ

के

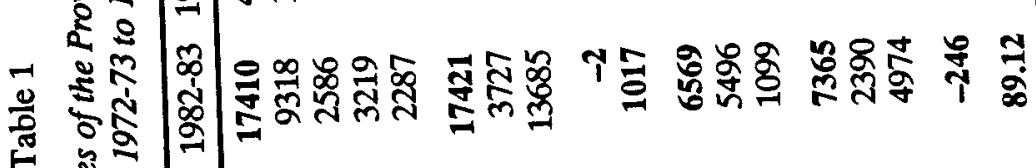

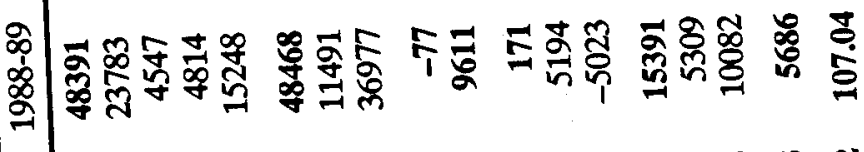

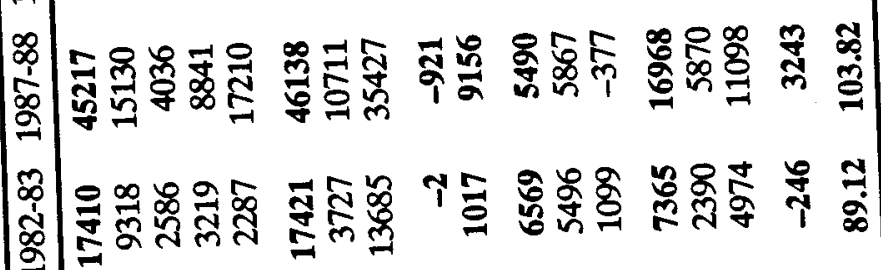
5

F

\&

密

궁ํํ윰동

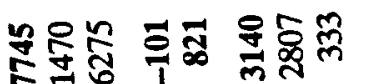

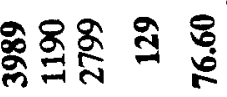

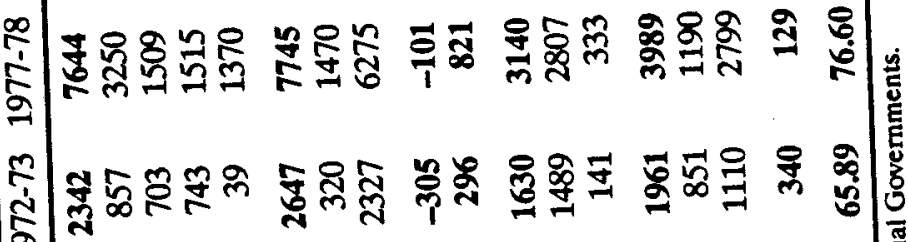

它

棺

甹焉焉

察管

훙

类焉

\%

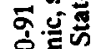

S.․․

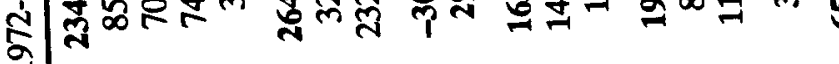

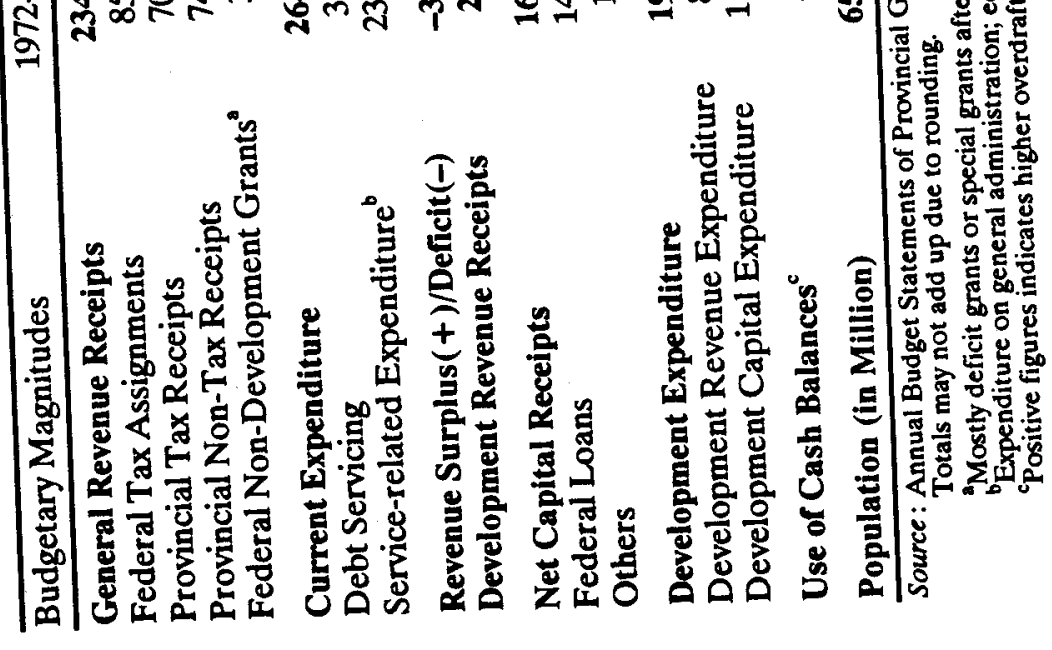


transfers had not improved the fiscal status of the provincial governments. There was fast growth simultaneously both in divisible pool transfers and in grants and the increasing inability of the provincial governments to generate revenue surpluses for self-financing part of their development programme. Furthermore, these ad hoc arrangements had resulted in significant budgetary strains on the federal government also. In the 80s, upto 1987-88, almost one-third of the incremental federal budgetary deficit was due to the increase in deficit grants to the provinces.

In 1987-88, a ceiling was imposed on deficit grants to the provinces which led to some restraint in expenditures and additional fiscal effort. But in the absence of expanded divisible pool transfers, provinces had run into unsustainable deficits, with the use of cash balances (overdraft with State Bank of Pakistan) rising to over Rs 4.5 billion by 1990-91. Consequently, it had become essential to review the fiscal relations between the federation and the provinces to promote the process of decentralisation, to expand the availability of resources of lower levels of government and to improve generally the efficiency in the mobilisation and utilisation of resources. This has become especially important in the current context when the country is confronted with high and rising budget deficit and higher resource mobilisation by all levels of government has assumed vital importance.

The purpose of this paper is to review if the recently announced NFC award helps in meeting these objectives. Using a theoretical model, it aims to study ${ }^{2}$ historically the nature of provincial fiscal response to federal transfers and borrowings from the viewpoint of their impact on the level of own revenue generation and expenditure. Also, it attempts to answer a number of questions relating to the magnitude of the increase in the transfers to the provinces as a whole and the implications of the new provisions on the fiscal behaviour of provinces. Section 2 describes the salient features of the new NFC award. Section 3 presents the theoretical framework of the analysis followed by the estimation methodology. Section 4 quantifies the dynamic consequences of the award on the four provinces combined. Finally, in Section 5, we present the major conclusions and policy implications emanating from the results.

\section{DESCRIPTION OF THE AWARD}

The NFC Award of 1991 expands the size of the divisible pool of taxes to include two additional taxes, excise duties on tobacco and tobacco manufactures and sugar. These taxes are to be shared between the federation and the provinces

${ }^{2}$ Study of the revenue-sharing formula for allocation among provinces from the divisible pool of taxes is outside the purview of this paper. 
on a 20:80 basis after allowing for costs of collection and distributed among the provinces on the basis of population. The award also transfers proceeds from development surcharge on natural gas, royalty on crude oil and net profits on hydel power generation to the province of collection. On top of this, special annual grants of Rs 700 million for five years to Sindh, one billion to Punjab, Rs 200 million to NWFP and Rs 100 million to Balochistan for three years each has also been announced.

The 1991 NFC award, distinguishes itself from the previous awards in a number of ways. First, it enhances provincial financial autonomy through a large increase in constitutionally mandated federal transfers, thereby reducing dependence on ad hoc grants and subventions from the federal government. In 1991-92, federal transfers were Rs 64 billion or 45 percent of total federal tax revenues. In the absence of the award, these transfers would have been Rs 39 billion, equivalent to 28 percent of federal tax revenues (see Table 2).

Table 2

Revenues Sources and Magnitude of Transfers to Provinces (Combined)

With and Without NFCAward of 1991 in 1991-92

(Rs in Billion)

Without 1991 NFC Award With 1991 NFC Award

Transfers Share(\%) Transfers Share(\%)

(A) Revenue Sources Shared on the Basis of Population

Income Tax

37.3

19.4

95.3

16.3

49.4

Sales Tax

1.5

41.7

Export Duty on Cotton

Excise Duty on Tobacco Manufactures

Excise Duty on Sugar

$\begin{array}{ll}- & - \\ - & -\end{array}$

(B) Revenue Sources Shared on the Basis of Collection Excise Duty and Royalty on Gas

Surcharge on Gas

Royalty on Crude Oil

1.8

1.8

4.7

$-\quad-$

Profits on Hydro-electricity

Total
$-$

39.1
4.7

3.9

$-$

$-$

100.0
47.6

19.4

16.3

1.5

6.8

3.5

16.4

1.8

7.4

1.1

6.0

64.0
74.4

30.3

25.5

2.4

10.7

5.4

25.6

2.9

11.6

1.8

9.4

(C) Divisible Pool Transfers as \% of Federal Tax Revenues

100.0

Source: Annual Budget Statements, of Provincial Governments. 
Second, the 1991 NFC award significantly improves the incentive environment and encourages financial discipline by the provinces. The discretionary element in grants has been eliminated and a system of fixed, special grants to each province has been instituted. This implies that provinces no longer have access to residual fiscal deficit grants. Furthermore, any surplus generated can be retained by the province. Therefore, by and large, provinces have been made responsible for their deficits/surpluses. In the absence of increase in borrowing powers the provinces are now compelled to exercise strict financial discipline.

We now proceed to set up the theoretical framework within the context of which the fiscal behaviour of the provincial governments to federal transfers in Pakistan can be explained. This will enable formal analysis of the effects of the 1991 NFC award.

\section{THEORETICAL FRAMEWORK}

The approach generally adopted for modelling the fiscal response of a government to transfers from a higher level of government is to assume that politicians/officials of the former maximise the utility of the typical citizen living in their jurisdiction subject to a budget constraint [Slack (1980); Henderson (1968)]. Utility is assumed to depend positively on the quantity of goods and services provided by the government and on the level of consumption of private goods. Therefore, the utility function can be stated as $^{3}$

$$
U=U[y-R, E]
$$

where $y=$ real per capita income, $R=$ real per capita revenue and $E=$ real per capita expenditure of

$$
\frac{\partial U}{\partial(y-R)}>0, \frac{\partial^{2} U}{\partial(y-R)^{2}}<0, \frac{\partial U}{\partial E}>0, \frac{\partial^{2} U}{\partial E^{2}}<0
$$

the provincial government $(y-R)$ corresponds to the level of consumption of private goods.

$R$ includes both tax and non-tax revenues while $E$ consists both of current and development expenditure. Aggregation is justified on the grounds that the difference between these two types of expenditure is not clear in practice. For households.

${ }^{3}$ For the typical citizen or median voter. These are the same given the assumption of identical 
example, current expenditures on education and health could legitimately be treated as development expenditure as they expand the productive capacity of the economy. Alternatively, a component of development expenditure is shown in the recurring budget and consists mostly of salaries and allowances of project related staff. We exclude, however, from expenditure payments for servicing of debt as these do not benefit citizens directly through provision of services.

The budget constraint (at current prices) can be expressed as;

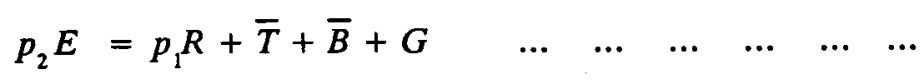

where $p_{2}=$ price index of public expenditure, $p_{1}=$ consumer price index, $T=$ per capita total intergovernmental transfers from the divisible pool of federal taxes as per the provisions of NFC award, $\bar{B}=$ per capita borrowings by the provincial government. These are also assumed to be exogenous as, under the Constitutional provisions, borrowings on behalf of the provincial governments consist of federal loans as part of the annual development programme (ADP), net capital receipts and use of cash balances with the State Bank of Pakistan. ${ }^{4}$

$G$ consists of grants from the federal government. Prior to the 1991 NFC award these consisted of two types of grants, lump sum grants and deficit grants. The former were given as subventions for performance of various agency functions, for special development programmes, etc. Deficit grants had increasingly been given, as highlighted earlier, to cover budget deficits of provincial governments due to the paucity of resources caused by the delay in the updating of revenue sharing arrangements. Therefore, total flow of grants was given by

$$
G=G_{0}+m\left[p_{2} E-p_{1} R-\bar{T}-G_{0}\right], 0<m<1 \quad \ldots \quad \ldots \quad \ldots \quad \ldots
$$

Over time, provinces had begun to operate in a framework of 'rational expectations' about these deficit grants and base their decisions about the level of taxation and expenditure on these expectations.

Substituting (3) into (2) we obtain,

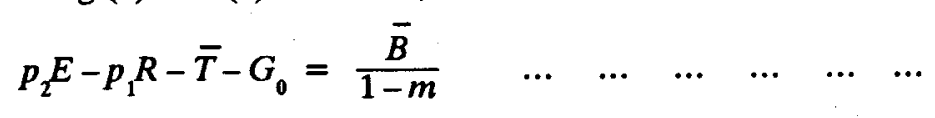

This is the revised formulation of the budget constraint in the presence of deficit grants. The stimulatory effect of these grants on the level of expenditure

${ }^{4}$ Provincial governments have a limited over-draft facility with the State Bank of Pakistan. 
and the negative impact on fiscal effort can be seen from (4) as follows:

$$
\text { as } m \rightarrow 1, E \rightarrow \infty, \quad R \rightarrow-\infty
$$

This explains why the resort to ad hoc deficit grants by the federal government had led to a profligacy in expenditure on the part of provincial governments and poor mobilisation of resources from own revenues.

The budget constraint can be written as

$$
p_{1}(y-R)+p_{2} E=p_{1} y+\bar{T}+G_{0}+\frac{\bar{B}}{1-m}
$$

Based on (1) and (4) we can set up the utility maximisation problem as follows:

$$
\mathcal{L}(R, E, \lambda)=U(y-R, E)+\lambda\left[I-p_{1}(y-R)-p_{2} E\right] \quad \ldots \quad \ldots
$$

where

$$
I=p_{1} y+\bar{T}+G_{0}+\frac{\bar{B}}{1-m} \text {. }
$$

The first order conditions are as follows:

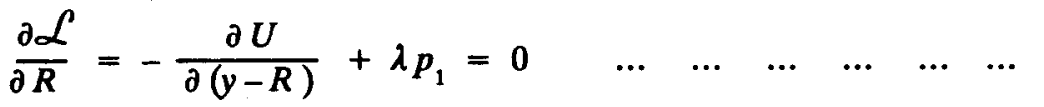

$$
\begin{aligned}
& \frac{\partial \mathcal{L}}{\partial E}=\frac{\partial U}{\partial E}-\lambda p_{2}=0 \\
& \frac{\partial \mathcal{L}}{\partial \lambda}=I-p_{1}(y-R)-p_{E}=0
\end{aligned}
$$

In particular it may be noted from differentiation of Equation (4) that

$$
\frac{\partial\left(p_{2} E\right)}{\partial T}-\frac{\partial\left(p_{1} R\right)}{\partial T}=1
$$

This is the standard result and highlights the fact that a one rupee increase in transfers due to NFC provisions is distributed partially in increased expenditure and partially in reduced taxation. The precise sharing of the impact is an empirical question to which we turn to in the next section. 


\section{ESTIMATION}

For estimation purposes, we specify the utility function explicitly as follow:

$$
U=\left(Y-R-y_{0}\right)^{\alpha}\left(E-E_{0}\right)^{1-\alpha}, 0<\alpha<1
$$

This is analogous Stone-Geary utility function. Substituting the derivatives of this function into (6) and (7) respectively, we obtain

$$
\begin{array}{lllllll}
-\frac{\alpha U}{Y-R-Y_{0}}+\lambda p_{1}=0 & \cdots & \cdots & \cdots & \cdots & \cdots & \cdots \\
\frac{(1-\alpha) U}{E-E_{0}}-\lambda p_{2}=0 & \ldots & \cdots & \cdots & \cdots & \cdots & \cdots
\end{array}
$$

This yields

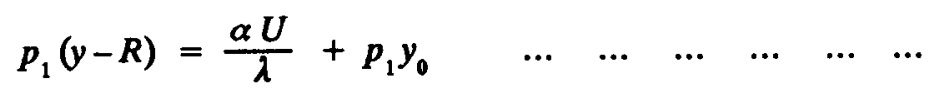

and

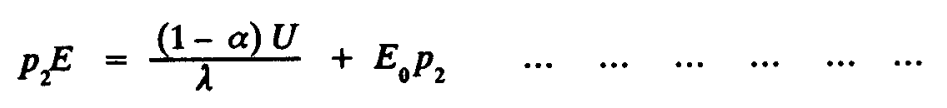

Substituting into (4) gives

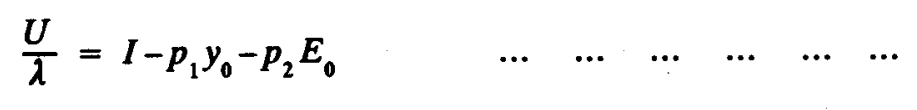

Substitution into (14) yields the following equation for public expenditure,

$$
p_{2} E=\alpha E_{0} p_{2}-(1-\alpha) p_{1} y_{0}+(1-\alpha)\left(p_{1} y+\bar{T}+G_{0}\right)+\frac{(1-\alpha)}{(1-m)} \bar{B}
$$

At this stage we make the assumption that the minimum bundle, $y_{0}$, rises with income. That is,

$$
y_{0}=a_{0}+a_{1} y
$$

Therefore, we have finally the expenditure equation for estimation purposes as follows:

$$
\begin{aligned}
p_{2} E= & \left(\alpha E \partial p_{2}-\left[(1-\alpha) a_{0}\right] p_{1}+\left[(1-\alpha)\left(1-a_{1}\right)\right]\left(p_{1} y\right)\right. \\
& +(1-\alpha)+\left(T+G_{0}\right)+\frac{(1-\alpha)}{(1-m)} B \quad \ldots r
\end{aligned}
$$


Substitution into (4) yields the revenue function as follows:

$$
\begin{aligned}
& p_{1} R=\left(\alpha E_{0}\right) p_{2}+\left[(1-\alpha) a_{0}\right] p_{1}+\left[(1-\alpha)\left(1-a_{1}\right)\right] p_{1} y-\alpha \\
& \begin{array}{llllllll}
\left(\bar{T}+G_{0}\right)-\frac{\alpha}{(1-m)} \bar{B} & \ldots & \ldots & \ldots & \ldots & \ldots & \ldots
\end{array}
\end{aligned}
$$

It may be noted from (16) and (17) that

$$
\frac{\partial\left(p_{2} E\right)}{\partial T}=(1-\alpha), \frac{\partial\left(p_{1} R\right)}{\partial T}=-\alpha
$$

and condition (9) is satisfied. Also, estimation of Equation (16) will yield the coefficients of Equation (17).

The above model has been estimated for the four provincial governments combined. Individual province level analysis was not possible because of basic data limitations, for example, the non-availability of estimates of provincial gross regional products. Annual Budget Statements of the individual provinces have been used to generate the aggregate data base for key provincial budgetary magnitudes like total expenditures (recurring + development), federal transfers and borrowings.

Equation (16) is estimated for the period, 1972-73 to 1990-91, prior to the 1991 NFC award. Results of estimation are as follows:

$$
\begin{aligned}
& P_{2} E=0.0299\left(P_{1} y\right)+0.6137\left(\bar{T}+G_{0}\right)+0.8967 \bar{B}+90.0497 P_{2}- \\
& (3.276)^{*} \\
& (6.602)^{*} \\
& (7.345)^{*} \quad(7.003)^{*} \\
& \begin{array}{ll}
83.2280 P_{1} & +51.7889 D \\
(-2.646)^{*} & (3.461)^{*}
\end{array} \\
& \vec{R}=0.997 \quad D-W \text { Statistic }=2.60
\end{aligned}
$$

*Significant at 1 percent level.

Equation (18) shows that a one-rupee increase in federal transfers leads to as much as a 61 paisas increase in provincial expenditure. The remaining 39 paisas are absorbed in a reduction of provincial fiscal effort. This result is in contrast to the earlier results of Slack (1980) for Canada in which bulk of the adjustment due to increased transfers is on the revenue side. The result indicates that in Pakistan 
a higher premium is placed on the increase in expenditure rather than on a reduction in fiscal effort.

The other result of interest is the high stimulatory impact of borrowings on expenditure. A rupee of borrowing leads to almost a 90 paisas increase in provincial expenditure. This is because of the non-zero value of $m$ in Equation (16) which gives the proportion of the revenue deficit financed by revenue deficit grants. The estimated magnitude of $m$ is about 0.30 . This implies that prior to the 1991 NFC award about 30 percent of the basic budget deficit of the provinces was met through deficit grants.

Furthermore, increase in the unit costs of public administration, primarily due to periodic pay awards, also has had a significant positive impact on provincial liabilities. Finally, the mid 80 s witnessed a spur in expenditures by the provincial governments due to the Five Point programme announced by the Junejo Government. The average growth rate of provincial governments during this period was about 21 percent. The growth in current expenditures was particularly high. This phenomenon is reflected by the positive and significant dummy ${ }^{5}$ variable, $D$, for the period in Equation (18). On the whole, increase in GDP, federal transfers, provincial borrowings, unit cost of public administration and the implementation of the five point programme largely explain the increase in provincial expenditures during the period of analysis. The model successfully explains bulk of the variation in provincial expenditure.

\section{DYNAMIC CONSEQUENCES OF AWARD}

Given the above results, we are now in a position to derive the consequences of the 1991 NFC award on various budgetary magnitudes. Two years have elapsed since the award was announced and emerging trends have become visible. Table 3 compares the growth rates during the decade of 1980s under the previous regime of inter-governmental fiscal relations and those observed in the immediate aftermath of the award. Contrary to expectations, there is little change either in the growth rate of expenditure or of provincial own revenues. As highlighted above, there was a quantum jump in divisible pool transfers in 1991-92. The question is why this has not been translated into a corresponding increase in expenditure or decline in own revenues. This requires analysis of the various factors affecting expenditure and taxation decisions in the post-1991 NFC era.

The value of the dummy is as follows: 1 for $1985-86 ; 1.5$ for $1986-87 ; 2.0$ for $1987-88 ; 1$ for $1988-89$ and 0 otherwise. 


\section{Table 3}

Pre-and-Post-1991 NFC Award Rate of Growth in Key Budgetary Magnitudes (Provincial Govemments Combined) (Annual Growth Rate \%)

\begin{tabular}{lccc}
\hline & $\begin{array}{c}\text { Pre 1991 } \\
\text { NFC Award } \\
(1982-83 \text { to } \\
1990-91)\end{array}$ & $\begin{array}{c}\text { Post 1991 } \\
\text { NFC Award } \\
(1990-91 \text { to } \\
1992-93)\end{array}$ & $\begin{array}{c}\text { Difference } \\
\text { in Growth } \\
\text { Rate }\end{array}$ \\
\hline General Revenue Receipts & 16.0 & 26.8 & 10.8 \\
Federal Tax Assignments & 17.4 & 46.5 & 29.1 \\
Provincial Own Receipts $^{\mathrm{a}}$ & 10.6 & 9.7 & -0.9 \\
Federal Non-development Grants & 12.1 & -37.3 & -58.4 \\
Current Expenditure & 17.5 & 17.2 & -0.6 \\
Debt Servicing & 19.6 & 17.1 & -2.5 \\
Service-related Expenditure & 16.9 & 17.2 & 0.3 \\
Development Revenue Receipts & 26.3 & -19.9 & -46.2 \\
Net Capital Receipts & 13.7 & -5.8 & -19.5 \\
Federal Loans & 14.3 & 1.0 & -13.3 \\
Others & - & -89.1 & - \\
Development Expenditure & 15.5 & 14.3 & -1.2 \\
Total Expenditure & 16.4 & 16.2 & -0.2 \\
Use of Cash Balances & $-{ }^{b}$ & 5.9 & - \\
\hline
\end{tabular}

Source: Derived from Table 1.

sprovincial Tax + Non-tax Receipts.

begative Value in Base Year.

${ }^{\text {C } C u r r e n t ~ E x p e n d i t u r e ~+~ D e v e l o p m e n t ~ E x p e n d i t u r e ~-~ D e b t ~ S e r v i c i n g . ~}$

Given the cessation of deficit grants following the 1991 NFC award we have that, since 1991-92, $m=0$. Substituting this into Equation (16) we can derive the difference in expenditure in the presence and in the absence of the 1991 NFC award as follows:

$$
E^{\prime}-E=(1-\alpha)\left[\bar{T}^{\prime}-\bar{T}\right]+(1-\alpha)\left[\bar{B}^{\prime}-\bar{B}\right]+(1-\alpha) \bar{B}\left[1-\frac{1}{1-m}\right] \ldots \ldots
$$

Equation (19) presents the decomposition of the difference in expenditure in the presence and in the absence of the 1991 NFC award. The first component 
gives the impact of the increase in divisible pool transfers (plus lump sum grants) from $\bar{T}$ to $\bar{T}^{\prime}$ due to the expansion in revenue-sharing arrangements. The second term captures the effect of any decline in borrowings by the provincial governments from $\bar{B}$ to $\bar{B}^{\prime}$. It is likely that given the large expansion in divisible pool transfers the federal government has limited its transfers on other accounts. This is confirmed by Table 3. Large declines have occurred in the post 1991 NFC period in growth rates of non-development grants, development revenue receipts and of cash development loans as part of the ADP.

The third component of Equation (19) highlights the change in the incentive environment following major changes in the pattern of inter-governmental fiscal relations in 1991. The cessation of deficit grants has removed one major factor contributing to fast growth in expenditure by provincial governments. The resulting fall in $m$ to zero is likely to limit the level of expenditure.

Results of the decomposition exercise are presented in Table 4. As expected, the impact of increase in transfers on the current account on expenditure in sizeable. However, this is largely neutralised by the decline in borrowings and,

\section{Table 4}

Decomposition of the Difference in Provincial Expenditure in the Presence and in the Absence of the 1991 NFC Award

\begin{tabular}{cccccc} 
& $1991-92$ & $1992-93$ & & \multicolumn{2}{r}{ (Rs per Capita) } \\
\hline $\bar{T}^{\prime}$ & 451.5 & 485.7 & $\alpha$ & $1991-92$ & $1992-93$ \\
$\bar{T}^{a}$ & 227.8 & 245.7 & $(1-\alpha)\left[\bar{T}^{\prime}-\bar{T}\right]$ & 137.4 & 147.4 \\
$\bar{B}^{\prime}$ & 146.4 & 177.2 & $(1-\alpha)\left[\bar{B}^{\prime}-\bar{B}\right]$ & -48.8 & -62.4 \\
$\bar{B}^{b}$ & 225.9 & 278.8 & $(1-\alpha) \bar{B}\left[1-\frac{1}{1-m}\right]$ & -64.1 & -79.1 \\
$m^{\prime}$ & 0 & 0 & $E^{\prime}-E$ & 24.5 & 5.9 \\
$m$ & 0.316 & 0.316 & & &
\end{tabular}

Revenues from sharing of taxes which were part of the divisible pool prior to 1991.

${ }^{b}$ Borrowings by provincial governments in the absence of the 1991 NFC award are estimated from the following equation:

$$
\ln \overline{\mathrm{B}}=\underset{(12.234)}{4.2341}+\underset{(3.600)}{0.5581 t}-\underset{(-1.329)}{0.0309 t^{2}}+\underset{(-1.841)}{0.00078 t^{3}}-\underset{(-5.194)}{0.849 \ln \overline{\mathrm{T}}}+\underset{(2.132)}{0.7549 D_{2}}
$$

$\bar{R}=0.887, D-W=2.021$

where $t$ is a time variable with a value of 1 in 1972-73. $D_{2}$ is a dummy variable with a value of $1 \mathrm{from}$ 1990-91 onwards, zero otherwise. 
more importantly, by behavioural changes caused by the removal of deficit grants from the provisions of the 1991 NFC award. In fact, the difference between projected expenditures in the presence and in the absence of the award appears to have narrowed significantly in the first two post-1991 NFC years. Contrary to perceptions, therefore, the award has begun to exert a restraining effect on provincial expenditures despite the large expansion in the divisible pool. The primary reasons for this are lower transfers on the capital account and the pressure now on provincial governments to keep down the revenue deficit due to lack of access anymore to deficit grants from the federal government.

Table 5 gives the projected levels of expenditure according to Equation (16) in the absence and in the presence (with $m=0$ ) of the 1991 NFC award. The latter are compared with the actual magnitudes. Actual expenditures following the award appear to be somewhat higher by about 3 percent than these projected by the equation. This can largely be attributed to the fact that the Pay Committee award was implemented in 1991-92. The price index for the public administration and defence sector in the national income accounts does not appear to fully reflect the impact on wage levels of this award. The average increase in salary and allowances in different grades was over 15 percent whereas the index showed an increase of 9 percent in 1991-92.

Table 5

Projected and Actual Levels of Provincial Expenditure and Revenues, 1991-92 and 1992-93

(Rs in Million)

1991-92

1992-93 Growth Rate (\%)

Projected

In Absence of NFC Award[1]

In Presence of NFC Award[2]

79261

92174

$16.3 \%$

82147

92912

$13.1 \%$

Actual

In Presence of NFC Award[3]

84420

95850

$13.5 \%$

Difference (\%)

[1] and [2]

[2] and [3]

$3.6 \%$

$0.8 \%$

[1] and [3]

$2.8 \%$

$3.2 \%$

$6.5 \%$

$4.0 \%$

As highlighted above, we also observe a narrowing of the difference between actual expenditure following the NFC award and the projected expenditure in the 
absence of the award. It was 6.5 percent in 1991-92 and has fallen to 4 percent in 1992-93. On this basis, expenditure in the absence of the award may even be higher by 1995-96, the last year for which the award is operative.

\section{Budget Deficit}

We are finally in a position to derive the impact on the overall national budget deficit, as well as the effect separately of the NFC award on the budgetary position of the federal and provincial governments respectively. For this purpose we define the following: $E_{F}=$ expenditure by the federal government, $E_{P}=$ expenditure by the provincial governments, $R_{F}=$ revenues collected by the federal government, ${ }^{6} R_{p}=$ revenues collected by the provincial governments. Then, the overall budget deficit, $B D$, is given by,

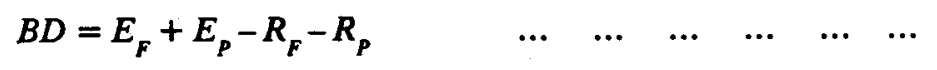

If we allow for intergovernmental transfers then

$$
B D=\left[E_{F}+G+T-R_{F}\right]+\left[E_{P}-R_{P}-G-T\right] \quad \ldots \quad \ldots \quad \ldots
$$

where $T=$ federal transfers from divisible pool plus lump sum grants and $G=$ deficit grants to provincial governments. The first part of Equation (21) is the budget deficit, $B D_{F}$, due to the federal government and second part is $B D_{P}$, the budget deficit due to provincial governments. Therefore, changes due to the NFC award can be expressed as follows:

and

$$
\begin{aligned}
& \Delta B \dot{D}_{F}=\Delta E_{F}+\Delta G+\Delta T-\Delta R_{F} \quad \ldots \quad \ldots \quad \ldots \quad \ldots \quad \ldots
\end{aligned}
$$

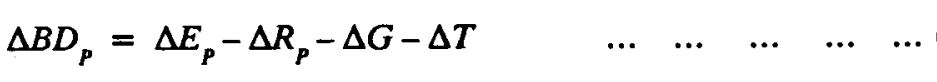

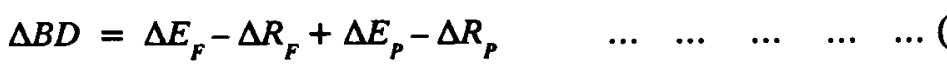

On the basis of Equations (3), (6) and (17) we derive the magnitudes of $\Delta G, \Delta E_{p}$ and $\Delta R_{p}$ respectively. Behavioural changes by the federal government due to the NFC award are outside the purview of this paper. Therefore, we assume that $\Delta E_{F}=0$ and $\Delta R_{F}=0$. In fact, there is some indication that the federal government has raised its level of fiscal effort in 1991-92 and 1992-93. 
Given the above accounting identities and assumptions, the impact of the NFC award on the federal budget deficit consists primarily of the increase in unconditional transfers on the current account less the savings due to the cessation of deficit grants. For the provincial governments, the change in budget deficit is due to change in expenditure, own revenues, transfers and deficit grants. The combined change on the national budget deficit is primarily the change in provincial expenditure and own revenues caused by the award.

The estimated changes are presented in Table 6. The major conclusion is that the overall impact of the 1991 NFC award on the national budget deficit is not large, at about 0.4 percent of the GDP in 1991-92 and marginal in 1992-93. However, the impact on the federal deficit is sizeable at close to 1 percent of the GDP in both years.

Table 6

Impact of 1991 NFC Award on the Budget Deficit

(Rs in Million)

\begin{tabular}{crr}
\hline & $1991-92$ & $1992-93$ \\
\hline Impact oN Federal Budget Deficit & \\
$\Delta G$ & -12244 & -15572 \\
$\Delta T$ & 26240 & 29010 \\
$\Delta B_{F}$ & 13996 & 13488 \\
$\Delta B_{F}$ as \% of GDP & $1.15 \%$ & $0.99 \%$ \\
Impact on Provincial Budget Deficit & & \\
$\Delta E_{P}$ & 2886 & 738 \\
$\Delta G$ & -12244 & -15572 \\
$\Delta T$ & 26240 & 29010 \\
$\Delta R_{P}$ & -1788 & -422 \\
$\Delta B D_{P}$ & -9322 & -12278 \\
$\Delta B D_{P}$ as \% of GDP & $-0.77 \%$ & $-0.90 \%$ \\
Impact on National Budget Deficit & & 1210 \\
$\Delta B D$ & 4674 & $0.09 \%$ \\
$\Delta B$ as \% of GDP & $0.38 \%$ &
\end{tabular}

\section{SUMMARY OF CONCLUSIONS AND POLICY IMPLICATIONS}

This paper has analysed the fiscal response of the provincial governments to transfers from the federal government. Results of estimation within the framework 
of a theoretical model reveal that for a one-rupee increase in transfers, there is, on the average, a 61 paisas increase in current expenditure and a decline in ownrevenues of about 39 paisas. Results further indicate that a corresponding increase in borrowings has a greater stimulatory impact, of about 90 paisas, on provincial expenditure. Consequently, the sizeable increase historically in divisible pool transfers accompanied by the increase in borrowings and grants has actually led to a deterioration in the budgetary position of the provinces.

However, contrary to expectations, the 1991 NFC award exerts a restraining effect on provincial expenditures despite the large expansion in the divisible pool of taxes. This is primarily due to lower transfers on the capital account and elimination of revenue deficit grants. Indications are that expenditure in the presence of the award may even be lower by $1995-96$, the last year for which the award is operative, than would otherwise have been the case.

Another major conclusion is that even though the impact of the 1991 NFC award on the federal budget deficit is sizeable, close to 1 percent of the GDP, from the viewpoint of the overall national budget deficit it is marginal.

The above consequences are largely due to the change in the incentive environment and a degree of financial discipline introduced by the NFC award. It is therefore important that the spirit of the award be preserved and the federal government must resist in particular any pressure to give deficit grants once again to the provinces.

Also, given that bulk of the adjustment of increased federal transfers is on the expenditure side, regulatory measures are required to ensure efficient utilisation of resources. These include, for example, a general ban on social employment. Special permission to hire additional staff should only be given for project related employment as new facilities are constructed and commissioned. The decision by the federal government to give matching development grants to provincial governments for higher fiscal effort [measured by revenues generated from taxation proposals during a particular fiscal year] is also a step in the right direction and may help in sustaining provincial revenues in the presence of a large increase in divisible pool transfers.

Finally, the paper has attempted analysis of the consequences of the 1991 NFC award for the four provinces combined. If reasonable regional income estimates or proxies become available then the analysis may be extended to determine the differential impact on each provincial government. This will enable appropriate corrective action to be taken in the next award, due after 1995-96. 


\section{REFERENCES}

Henderson, James M. (1968) Local Government Expenditures: A Social Welfare Analysis. The Review of Economics and Statistics 50: May 156-63.

Slack, Enid (1980) Local Fiscal Response to Inter-governmental Transfers. Review of Economics and Statistics. 


\section{Comments on}

\section{"Dynamic Budgetary Consequences of the 1991 NFC Award"}

The paper is quite interesting and topical as it examines the effect of the 1991 NFC award on the budgetary deficits of the provincial governments. It comes up with interesting conclusions regarding the impact of the transfers of the federal government on the expenditures and resource mobilisation efforts of the provincial governments. My comments on the paper relate to the specification of the model, econometric estimation and the conclusion drawn from the analysis.

The model specifies a utility function in terms of revenue and expenditure diverging from a specified limit. Notwithstanding the fact that development and non-development expenditures have different implications for growth, they have been pooled together. How the distinction between these two types of expenditures would affect the results needs to be explored. Even more importantly, there are problems with the specification of the model. It assumes that the utility function is homogenous of degree zero but no attempt has been made to test the degree of homogeneity. Moreover, the utility function taken as the differential in the revenue and expenditures from the base values can explode if both the expenditure and revenues have the same coefficient. The implications that the two coefficients would diverge are not less serious either. Similarly, the specification of the constraint is a little odd. It is a constraint, which can also be modified as soon as expenditures increase. Probably, the constraint needs to be reformulated. Moreover, the lag adjustments have been completely ignored.

In the econometric specification the variable $p$ appears on both sides of the equation, though they have a different subscript. Are the two prices not necessarily the same? And if they are then would it not lead to spurious results and as such the high $\bar{R}^{2}$ may be just a reflection of the specification.

The paper makes a comparison of federal transfers as a percentage of total tax revenues. Since grants were the major component prior to $1990-91$, a proper comparison would be the total amount of federal resources transferred to provincial government including grants and share in revenue to the NFC award.

The paper comes to the conclusion that an increase in one rupee of provincial transfer would reduce the resource mobilisation by 39 paisas. If the 